УАK 616.314-089.87-06-08-084

(СЮ. О. Рошка, Я. В. Горицький, О. Ю. Гаген

Буковинський державний медичний університет, м. Чернівці

\title{
Альвеоліт: сучасний стан проблеми
}

Резюме. У статті подано причини, механізми розвитку, клініку та лікування альвеоліту. Матеріали підібрано на підставі огляду літературних джерел і досвіду авторів.

Ключові слова: альвеоліт, діагностика, сучасні методи лікування.

\section{Ю. А. Рошка, Я. В. Горицкий, А. Ю. Гаген}

Буковинский государственный медицинский университет, г. Черновцы

\section{Альвеолит: современное состояние проблемы}

Резюме. В статье представлены причины, механизмы развития, клиника и лечение альвеолита. Материалы подобраны на основании обзора литературных источников и опыта авторов.

Ключевые слова: альвеолит, диагностика, современные методы лечения.

\author{
Yu. O. Roshka, Ya. V. Horytskyi, O. Yu. Hahen \\ Bukovyna State Medical University, Chernivtsi
}

\section{Alveolitis: current state of the problem}

Summary. The article presents the causes, development mechanisms, clinical features and treatment of alveolitis. Materials are selected based on the literature review and the authors' experience.

Key words: alveolitis, diagnosis, current treatments.

Вступ. Питання профілактики та лікування післяопераційних ускладнень при операції видалення зуба залишається актуальним Аля сучасної хірургічної стоматології.

Видалення зуба - найпоширеніша операція в амбулаторній хірургічній стоматології. У нормі після видалення ямка повинна загоюватися декілька днів. Біль вже через добу відсутній. У випадку відсутності згустка рана інфікується, виникає альвеоліт і репаративні процеси уповільнюються.

Альвеоліт - це досить поширене запальне ускладнення після проведення операції видалення зуба, що супроводжується симптомами, провідними з яких є біль у ямці з іррадіацією та частковий або повний розпад кров'яного згустка. При цьому альвеоліт (локальний остеїт) розвивається в $2-3 \%$ випадків після простого видалення зубів і у 20 \% пацієнтів після атипової екстракції. Аані літератури свідчать про зростання даного ускладнення в хірургічній стоматологічній практиці.

Матеріали і методи. Здійснено аналітичний огляд сучасної української та зарубіжної літератур, де розглядається етіологія, клініка, лікування та профілактика альвеоліту.

Результати досліджень та їх обговорення. Основними етіологічними факторами у виникненні цього ускладнення є:

- мікробний фактор (вогнище інфекції, що розташоване в періапікальних тканинах);

- травматичне видалення зуба. 
При цьому відбувається деструкція згустка крові, нерідко прогресування процесу, що розвинувся у ямці зуба до його видалення [5].

Біль у ямці - головна скарга пацієнта, яка виникає внаслідок впливу мікроорганізмів та ïх токсинів на нервові закінчення в оголеній стінці кісткової альвеоли.

Найчастіше у розвитку альвеоліту беруть участь золотистий і епідермальний стафілокок, диплокок, гемолітичний стрептокок.

Провідна роль належить патогенній інфекції, яка розвивається при відсутності згустка крові або його передчасному руйнуванні в ямці видаленого зуба. Цьому сприяє порушення післяопераційного режиму: надмірне полоскання ротової порожнини вимиває сформований згусток крові з ямки і патогенним мікроорганізмам нічого не заважає викликати запалення. Ще одним етіологічним фрактором є недостатній рівень гігієни та потрапляння залишків їжі в ямку видаленого зуба [2].

У зв'язку з розвитком сучасних місцевих анестетиків найчастіше причиною розвитку альвеоліту є надмірна інфільтрація тканин анестезуючою речовиною з вазоконстриктором. Адже надмірне використання судинозвужувальних препаратів, які вводять разом 3 місцевими анестетиками, призводить до тривалого спазму судин і перешкоджає утворенню в ямці зуба кров'яного згустка, внаслідок цього формується «суха ямка».

Аля оптимального загоєння ямки видаленого зуба необхідна наявність у ній кров'яного згустка. Однак на відміну від загальнохірургічних втручань, операція видалення зуба в більшості випадків не завершується накладанням швів. Тому природним наслідком при видаленні зуба $є$ кровотеча з ямки, що триває $5-10$ хв і закінчується утворенням кров'яного згустка, наявність якого призводить до загоєння кісткової рани. Крім того, процеси місцевого гемостазу в порожнині рота перебігають за участю ротової рідини, що містить сполуки, які володіють тромбопластичними, фібринолітичними та антикоагуляційними властивостями [1].

Однак не у всіх випадках кровотеча зупиняється самостійно і може продовжуватися тривалий час внаслідок:

1) травматичного видалення зуба з розривом або розчавленням слизової оболонки;
2) відлому частини альвеоли, міжкореневої або альвеолярної перегородки;

3) видалення зуба під час гострого запального процесу;

4) пошкодження артеріол;

5) надмірної інфільтрації тканин анестетиками з вазоконстрикторами, що призводить до тривалого спазму судин;

6) захворювання, що характеризуються порушенням процесу згортання крові або порушеннями судинної системи (геморагічні діатези, гострий лейкоз, інфекційний гепатит, септичний ендокардит, висипний і черевний тифи, скарлатина та ін.);

7) прийому антикоагулянтів прямої і непрямої дії;

8) гіпертонічної хвороби.

Тампонада ямки, недотримання хворими рекомендацій лікаря (полоскання порожнини рота після операції видалення зуба, куріння, вживання алкоголю) також можуть бути причиною порушення утворення кров'яного згустка. Руйнування його може відбутися також за рахунок фібринолітичної дії слини.

Тривала кровотеча з ямки видаленого зуба часто призводить до пізнього утворення кров'яного згустка, його неповноцінності, інфікування рани, i, як наслідок, розвитку альвеоліту.

Відзначено, що операція видалення зуба ускладнюється ямковими кровотечами у 0,25-0,44 \% хворих, які є первинними і вторинними. У 77,4 \% випадках пов' язані з місцевими причинами, а в $22,6 \%$ - із загальними. Встановлено, що частота виникнення кровотеч після операції видалення зуба серед інших ускладнень становить $15,4-15,9 \%$. Кровотечі після операції видалення зуба частіше спостерігають у хворих віком $16-45$ років (у $64 \%$ випадків), особливо після видалення молярів нижньої щелепи (60%). Крім того, у 99 \% випадків кровотечі були зумовлені місцевими причинами $[2,6]$.

У зв'язку з цим, основна роль у зупинці ямкової кровотечі й, отже, в профілактиці утворення «порожньої» або «сухої» ямки, належить методам місцевого гемостазу.

Аля зупинки кровотечі запропоновано різні способи і засоби гемостазу: перев'язка судин, припікання кристалами марганцю, стиснення стінок ямки щипцями, накладання швів, 
туга тампонада ямки йодоформною турундою. Однак перераховані методи мають суттєві недоліки:

- досить травматичні;

- викликають опік слизової оболонки порожнини рота;

- сприяють виникненню запальних процесів;

- погіршуютьперебіг репаративних процесів.

Аля місцевого гемостазу рекомендують використовувати пухку тампонаду ямки турундою, змоченою 5 \% розчином епсилон-амінокапронової кислоти з призначенням перорально дицинону, 10 \% розчину хлористого кальцію, аскорбінової кислоти і рутину, препаратом «Каталюгем», що має кровоспинну дію. Однак введення в ямку зуба турунди має суттєвий недолік - при її вилученні разом 3 нею відділяється і кров' яний згусток, що призводить до рецидивів кровотечі.

Аеякі автори пропонують присипати ямку видаленого зуба порошком епсилон-амінокапронової кислоти, інші рекомендують спосіб струминного введення в ямку біологічного клею МК-7 за допомогою безголкового ін'єктора. Є відомості про використання біопрепаратів: антисептичного біологічного порошку «РС», розчину тромбіну, кетгуту, фібринової плівки і біопластика. Проте два останніх приклади мають слабкі гемостатичні властивості, а інші препарати, хоча і володіють достатньою кровоспинною дією, але через відсутність пластичних властивостей швидко вимиваються з ямки. Ось чому гемостатичний ефрект є короткотривалим.

Виражений гемостатичний ефект дозволяє введення в ямку біологічно гемостатичних препаратів, що розсмоктуються та виготовлені з крові людини (гемостатична губка); крові та тканин тварин (гемостатична колагенова губка). Крім того, відзначено позитивну дію желатинової губки «Кровостан», антисептичної губки з гентаміцином, гемостатичної губки з Амбене.

Проведений аналіз літературних даних свідчить, що проблема попередження ямкових кровотеч та місцевого гемостазу після видалення зуба залишається актуальною, тому застосування сорбенту «Целофрорм» Аля цього є досить перспективним і заслуговує подальшого вивчення [1].

Місцеве лікування альвеоліту передбачає комплексний підхід: видалення некротичного розпаду з ямки, шляхом оперативного втручання (кюретаж) та призначення медикаментозної терапії. Особливо важливе значення має лікування гнійно-некротичних та некротичних альвеолітів, які найчастіше при неадекватному лікуванні ускладнюються остеомієлітом ямки з секвестрацією кісткових країв альвеоли, що посилює атрофрічні зміни альвеолярного відростка.

Аля лікування альвеліту запропоновано безліч препаратів: «Альважил», «Неоконес», пасту Пінеліса та ін. Головні їх недоліки відносна тривалість лікування, необхідність повторного застосування. Існуючі думки щодо профілактики альвеоліту досить суперечливі. Прийнято вважати, що техніка екстракції з мінімальною травматизацією зменшує ймовірність розвитку даного ускладнення. Крім того, рекомендується попереднє полоскання порожнини рота розчинами антисептиків, введення в ямку різних турунд або губок, просочених антибіотиками, антисептиками.

Сприятливі результати для профілактики і лікування альвеоліту отримано при застосуванні антисептичної губки з канаміцином, гентаміцином.

Широке застосування Аля профілактики альвеолітів отримав препарат “Альвожил», який має антисептичну, анестезуючу та кровоспинну дії. Препарат випускають у вигляді пасти і джгутиків. Однак проведені дослідження показали, що цей препарат продовжує терміни загоєння рани після видалення зуба, отже, його можна використовувати тільки в якості лікування альвеоліту, що вже виник, але ніяк не у випадку профілактичного засобу [2].

Аля оцінки ефективності профілактики альвеоліту запропоновано комплекс лабораторних (лейкоцитарний індекс інтоксикації, імунний статус) і біохімічних (С-реактивний білок, фрібриноген, альбумін) показників [7].

Окремої уваги, на нашу Аумку, потребує проблема профілактики альвеоліту після атипового видалення зубів.

Це в основному стосується третіх нижніх молярів, які мають характерне топографоанатомічне розташування в тілі щелепи і проявляють тенденцію до пізнього та повільного прорізування. Багато авторів відзначає складність, травматичність і тривалість видалення зубів мудрості, що в післяопераційному періоді значно підвищує ризик виникнен- 
ня таких ускладнень, як альвеоліт, кровотеча, рефлекторна запальна контрактура жувальних м'язів, пошкодження чутливих нервів. Запальні ускладнення в післяопераційному періоді у таких пацієнтів виникають в $14-35$ \% випадків.

Враховуючи частоту післяопераційних ускладнень після видалення нижніх третіх молярів, для їх профілактики та лікування запропоновані різні медикаментозні засоби й методики їх застосування [3].

Запропоновано велику кількість засобів місцевого лікування альвеоліту. На нашу думку, їх можна поділити на такі групи: антибіотики, антисептики, мазі, пасти, суміші, сорбенти, біопластини, комплексні засоби.

Способи їх введення поділять на:

1) зрошення ямки зуба;

2) заповнення ямки зуба;

3) введення турунди в ямку зуба;

4) введення у слизову оболонку в ділянці ямки зуба.

Висновки. Існуючі методи профілактики альвеоліту, а також запропоновані для цього лікувальні засоби, не можуть повністю вирішити дану актуальну проблему, що вимагає їі подальшої розробки, подальшого вивчення.

Більшість наведених способів медикаментозного лікування спрямована на швидку ліквідацію запалення в ямці видаленого зуба з використанням антибактеріальних та проти-

\section{Список літератури}

1. Эффективность хирургической повязки из «Целоформа» для профилактики и лечения альвеолитов / Г. А. Ахмадуллина, С. С. Ксембаев, О. В. Нестеров [и др.] // Казанский медицинский журнал. - Казань, 2011. - № 1. - С. 37-41.

2. Гутор Н. С. Оптимізація діагностики, профілактики та лікування альвеолітів (експериментальноклінічне дослідження) : автореф. дис. на здобуття наук. ступеня канд. мед. наук : 14.01.22. - Стоматологія / Н. С. Гутор ; АУ Ін-т стоматології АМН України. - Oдеса, 2011. - 20 с.

3. Григорьянц $\lambda$. А. Профилактика и лечение осложнений, связанных с удалением нижнего третього моляра при его ретенции / $\Lambda$. А. Григорьянц, В. А. Белова, В. А. Бадалян // Стоматология. - 2009. - № 3. - C. $41-43$.

4. Губин М. А. Антибактериальная терапия в амбулаторной хирургической стоматологии / М. А. Губин, запальних засобів і призначенням знеболювальних препаратів.

Однак більшість препаратів для місцевого лікування не завжди забезпечує тривалий ефект на тканини запаленої ямки зуба, так як вони швидко вимиваються слиною, або видаляються самостійно при будь-якому мінімальному м'язовому навантаженні з боку органів порожнини рота. При цьому уповільнюються процеси грануляції, епітелізації і регенерації тканин запаленої ямки.

Серед численних засобів, які застосовують при місцевому лікуванні ран, нашу увагу привернула група медичних сорбентів, що забезпечують активну некролітичну та антисептичну дії на рану. Розробка методів місцевого лікування ран з їх використанням призвела Ао розвитку цілого напрямку, що отримав назву сорбційно-аплікаційної терапії. Активні меАичні сорбенти повинні мати необхідний рівень сорбційної властивості, перешкоджати всмоктуванню в тканини ексудату з рани, забезпечувати його відтік, видаляти мікробні тіла й продукти їх життєдіяльності, забезпечувати виражену протизапальну, знеболювальну, протинабрякову дії, створювати умови Аля оптимальних репаративних процесів у рані. Тому проблема пошуку засобів і методів профілактики та лікування альвеоліту залишається актуальною.

Ю. М. Харитонов, Б. В. Аунев // Стоматология. 2012. - Спец. выпуск. - С. 18-19.

5. Противоальвеолитная активная повязка / О. К. Поздеев, С. С. Ксембаев, О. В. Нестеров, Г. А. Ахмадуллина : матер. III Российской научно-практической конференции «Профилактика стоматологических заболеваний и гигиена полости рта». - Казань : Издательство «Отечество», 2010. С. 16-21.

6. Рожко М. М. Стоматологія : навч. вид. / Рожко М. М., Кириленко I. I., Аенисенко О. Г; за ред. проф. Рожко М. М. - К. : Книга плюс. - 2010. - Т. 2. - 545 с. 7. Яременко А. И. Иммунологическая реактивность у больных инфекционно-воспалительными процессами челюстно-лицевой области и способы иммунокоррекции / А. И. Яременко, Т. М. Лехова // Эндодонтия Today. - 2002. - № 3-4. - C. 46-51. 